\title{
Effects of vermicompost and plant growth enhancers on the exo-morphological features of Capsicum annum (Linn.) Hepper
}

\author{
Govindapillai Seenan Rekha ${ }^{1}$ Patheri Kunyil Kaleena ${ }^{1}$ - Devan Elumalai ${ }^{2} \cdot$ Mundarath Pushparaj Srikumaran $^{1}$. \\ Vellaore Namasivayam Maheswari ${ }^{1}$
}

Received: 17 February 2017 / Accepted: 20 December 2017 / Published online: 1 February 2018

(C) The Author(s) 2018. This article is an open access publication

\begin{abstract}
Purpose Vermicomposting is an environmentally and economically friendly process to decompose organic waste. India's agro-industrial sector contributes huge resources of plant materials in the form of compost. In this study, 50\% of vermicompost was compared with plant growth enhancers on the exo-morphological features of $C$. annum. A significant plant growth was recorded in plants treated with Vermicompost. The present study aims to promote soil health and its plant growth providing effects further substantiating the use of organic amendments instead of fertilizers. Vermicompost contains a combination of macro- and micro-nutrients and the uptake of the nutrients has a positive effect on plant nutrition, growth, photosynthesis and chlorophyll content of the leaves.

Methods Pot studies were carried out in ten replicates and four soil amendment treatments: (1) Control, $100 \mathrm{ml}$ distilled water (2) 50\% Vermicompost of soil (3) $10 \mathrm{ml}$ of Gibberellic Acid + $90 \mathrm{ml}$ deionised water (GA + $100 \mu \mathrm{g} / \mathrm{ml})-10 \mathrm{ml}$ Indole Acetic Acid $+90 \mathrm{ml}$ deionised water. Pots were planted with C. annum and the measurements of studied traits (length of shoot, length of internode, leaves number and number of branches were determined.

Results The effect of plant growth enhancers like GA, IAA was compared with 50\% vermicompost applications. Significant improvement in all the parameters, like length of shoot, length of inter node, number of leaves and number of branches was observed in plants at the end of $3 \mathrm{rd}, 4$ th and 5 th weeks of treatment.

Conclusion Plants treated with 50\% vermicompost showed significant growth than Gibberellic acid (GA)- and Indole acetic acid (IAA)- treated plants. These results clearly indicate that vermicompost can be exploited as a potent biofertilizer.
\end{abstract}

Keywords Vermicompost · Earthworm · Plant growth regulators · Gibberellic acid · Indole acetic acid

\section{Introduction}

India's agro-industrial sector contributes immense resources of plants nutrients in the form of wastes like animal manure, sewage sludge, food wastes and industrial organic wastes which is either terrified away or buried or burnt causing environmental pollution. Due to its terrible smell, costs involved in transport and fear that its appliance might lead to crust formation, pollution problems, $\mathrm{pH}$ variation, farmers are reluctant to apply it to their land (Karimi et al.

Patheri Kunyil Kaleena

drpkklab@gmail.com; pkkaleena@yahoo.co.in

1 Department of Zoology, Presidency College (Autonomous), Chennai 600 005, Tamilnadu, India

2 Department of Zoology, Pachaiyappa's College for Men, Kanchipuram 631 501, Tamilnadu, India
2017). Conventional composting of press mud takes about 6 months, does not remove the bad smell completely, has less nutritive value and is compacted. Vermicomposted pressmud using Lampito mauritii, Eudrilus eugeniae, Perionyx excavatus, Eisenia foetida can be converted into an eco-friendly organic fertilizer soil amendment and this pressmud vermicompost shows plentiful nutrient content and enzymatic microbial activities facilitating the easy uptake by the plants (Parthasarthi and Ranganathan 2002).

Innovative agriculture develops a rich food at reasonable rate, all year round. They are expected to be harmless and nutritious particularly fruits and vegetables, not having any blemishes. Over the year, growers and farmers have changed the way they develop food production to meet the anticipation of peoples, supermarket and governments (Ansari and Hanief 2013).

Vermicompost is a nourishing organic fertilizer having high amount of humus, nitrogen-2-3\% 
phosphorous-1.55-2.25\%, potassium-1.85-2.25\%, micronutrients, more beneficial soil microbes like 'nitrogenfixing bacteria' and mycorrhizal fungi. Vermicompost has been scientifically proved as miracle plant growth enhancer (Chaoui et al. 2003; Guerrero 2010). Ansari and Ismail (2012) reported that worm's vermicast contains $7.37 \%$ nitrogen and $19.58 \%$ phosphorous as $\mathrm{P}_{2} \mathrm{O}_{5}$.

Microbial population of $\mathrm{N}_{2}$-fixing bacteria and actinomycetes increases by the application of vermicompost. The amplified microbial activities improve the availability of soil phosphorous and nitrogen. Vermicomposting is an aerobic, biological method and is proficient to convert eco-friendly humus like organic substances (Chanda et al. 2011).

Vermicompost stimulates to influence the microbial activity of soil, increases the availability of oxygen, maintains normal soil temperature, increases soil porosity and infiltration of water, improves nutrient content and increases growth, yield and quality of the plant (Arora et al. 2011).

Among the insect pests, defoliators and pod borers during vegetative and post flowering stage are economically important causing significant yield loss (Singh et al. 2011); Extensive usage of inorganic fertilizers and pesticides in agriculture has lead to environmental issues like pesticide residuum in food commodities, bioaccumulation and biomagnifications of pesticides in food web and deprivation of soil health. Owing to wide spectrum of problems with the use of chemical insecticides, organic farming is fast becoming popular among the scientists and farming community. Vermicompost and vermiwash (a liquid fertilizer) play a vital role in organic-based unindustrialized system such as organic farming, sustainable farming or eco-friendly farming and in numerous ways account for crop nourishment, pests fighting processes and soil fertility enhancement (Varghese and Prabha 2014).

Plant growth regulators are known to control plants physiological and biochemical processes. These include control of dormancy, organ size, crop development, flowering and fruit set, regulations of chemical composition of plants and control of mineral soil (Elumalai et al. 2013).

Phytohormones play an important role in inducing and enhancing, various physiological activities in the plant. Synthetic growth regulators which include promoters as well as inhibitors have a significant role in raising the yield of the crop plants by increasing the process of transpiration. Most widely available plant growth regulator is gibberellic acid, which induces stem and inter node elongation, seed germination and fruit setting and growth (Ouzounidou et al. 2010).

Application of foliar spray in agriculture has been a popular practice with farmers since the 1950s when it was erudite that a foliar fertilizer was effective (Tejada and Gonzalez 2004). Growth enhancers of plant in general are organic compounds which bring about an increase or alteration of plant growth. Growth regulators are new generation of agrochemicals; when added in small amount as foliar sprays, they modify the normal growth, from seed germination to senescence in crop plants. The use of GA and NAA is of considerable interest in different fields of agriculture studies in various crops have inducted the beneficial effects of growth regulators on crop growth, fruit yield, seed yield and seed quality (Manjunath Prasad 2008).

Previous studies have reported that GA regulates cell division and elongation, and also shows growth promoting effects (Naeem et al. 2004). Indole acetic acid, GA and kinetin increase cell division (Fathima and Balasubramanian 2006). The effect of growth enhancers on the exomorphological characters of Abelmoschus esculentus and various combinations of plant growth enhancers when used as a foliar spray on A. esculentus plant showed maximum increase in height, internode length and diameter (Fathima and Balasubramanian 2006).

Growth and development events in plants are controlled by growth regulators and these phytohormones are found naturally in plants. Manufacturing and production of synthetic phytohormones are not economically feasible and the optimum conditions under which they can function efficiently are also difficult to ascertain (Gemici et al. 2000). Due to environmental pollution, health problems and reactions caused by artificial growth enhancers and their low biodegradability have urged us to search for new bio-fertilizers with growth regulating activities. In the present investigation, vermicompost was used to study the growth pattern of Capsicum annum in comparison with synthetic plant growth regulators such as GA, IAA.

\section{Materials and methods}

The experimental plant material, Capsicum annum (L) Hepper, belonging to family Solanaceae, commonly called chilly was selected for the study. Seed samples were procured from Indian Agro centre, Arakkonam, Vellore to raise plants for the experiments. The plant growth parameters of this plant have been studied using vermicompost in comparison with the plant growth enhancers such as Indole acetic acid (IAA) and Gibberellic acid (GA) administered as foliar sprays.

\section{Preparation of vermicompost}

Vermicompost was prepared in pits with suitable dimensions. The pit was $2 \mathrm{~m}$ in length and $1 \mathrm{~m}$ in width and depth. Base of the pit was filled with layer of broken bricks, followed by a layer of sand to restrict the earthworms movement towards the soil, $15 \mathrm{~cm}$ of the pit was then filled with loamy soil or garden soil and small lumps of fresh cattle dung were sprinkled at random. This acts as an active growing medium for earthworms. About 100-500 earthworms 
(Eudrilus eugeniae, Perionyx excavatus, Eisenia foetida) were introduced in the vermibed. $10 \mathrm{~cm}$ thick layer of straw, leaf litter and various farm residues were placed above it. Slurry of Cow dung was sprinkled. The same set of layers was continued till a height of $1 \mathrm{~m}$ and sprinkled with water to retain in the moisture content. Harvesting was done on 45th day, and the worms were separated from the vermicast. The young worms and cocoons were separated from the soil using $3 \mathrm{~mm}$ sieves. The vermicompost contains macro and micro nutrients (Ismail 2005).

\section{Experiment}

Pot studies with $C$. annum were carried out by using vermicompost and foliar spray as plant growth regulators with deionized water was used for control to study the difference in the exo-morphological features in response to their treatments. Teepol solution of $0.01 \%$ was added with foliar spray, which acts as a surfactant enhancing the adherence of the spray solution to the leaves. With the help of an atomizer, spray solution was sprayed. Applications of 50\% vermicompost and plant growth enhancers were used as a foliar spray for C. annum are given in Table 1.

C. annum seedling was raised in broad pots, i.e., width of $60 \mathrm{~cm}$, and changed into small pots. Red soil, sand and farm yard manure in the ratio of 1:1:1 were filled in the pots; plants were maintained under the garden land conditions. Ten plant replicates were maintained in three pots for treated and control groups. Throughout the experimental period, plants were irrigated by water with well and uniformly. When the plants were 10 days old, the experiment was started since it has a life cycle of 90-100 days only. The spraying was done at the end of each week for five successive weeks. The following exo-morphological features were carried out in treated and control groups.

\section{Study of exo-morphological features}

At the end of every week of spray and at $0 \mathrm{~h}$, i.e., just before giving the spray application, the following exo-morphological data were recorded in the control and treated

Table 1 Showing the vermicompost and various plant growth regulators (PGRs)

\begin{tabular}{lll}
\hline S. No & Treatment (PGRS) & Concentration \\
\hline 1. & Control & $100 \mathrm{ml}$ deionised water \\
2. & Vermicompost- $(50 \%)$ & $50 \%$ vermicompost + soil \\
3. & IAA $(100 \mu \mathrm{g} / \mathrm{ml})$ & $10 \mathrm{ml} \mathrm{IAA}+90 \mathrm{ml}$ deionised water \\
4. & GA $(100 \mu \mathrm{g} / \mathrm{ml})$ & $10 \mathrm{ml} \mathrm{GA}+90 \mathrm{ml}$ deionised water \\
\hline
\end{tabular}

plants. Experiments were repeated thrice to make sure that the results were uniform and the following parameters were analyzed, (1) length of the plants, (2) inter node length, (3) number of leaves and (4) number of branches.

\section{Measurements of plant growth parameters}

Length of shoot and inter node $(\mathrm{cm})$ was measured with a measuring tape and the data were recorded. The number of leaves and branches was counted manually.

\section{Statistical analysis}

Data on morphological parameters were subjected to statistical analyses. All data were given as mean and standard error. The differences between the treatment groups and controls were statistically analyzed. The level of significance was set at $P<0.05$.

\section{Results}

The morphological parameters like shoot length, intermodal length, number of leaves and number of branches was recorded at an interval of 1 week (7 days) for 5 weeks in control and experimental groups.

\section{Length of shoot}

There is a significant difference in shoot length between control and treated plants. Length of the shoot at the beginning of first week, i.e., at the time of treatment was $8.5 \mathrm{~cm}$. A considerable increase in shoot length was recorded in treated plants; when compared to control plants length of the shoot of plants treated with vermicompost $50 \%$ $(22.14 \mathrm{~cm})$, GA $(20.14 \mathrm{~cm})$, IAA $(18.14 \mathrm{~cm})$ was significantly higher than in control (10.67) plants (Table 2).

\section{Length of internode}

Average intermodal length at the time of treatment was $0.1 \mathrm{~cm}$. After the treatment, significant increase in the intermodal length of the treated groups was observed compared to control plants. Maximum intermodal length was observed in $50 \%$ vermicompost treatments $(2.97 \mathrm{~cm})$ followed by GA $(2.17 \mathrm{~cm})$-, IAA $(1.77 \mathrm{~cm})$-treated plants than in control plants $(1.66 \mathrm{~cm})$ at the end of fifth week (Table 3). 


\section{Number of leaves}

At the zero hours average number of leaves was 2.0 vermicompost $50 \%$ treated plants, showed maximum number of leaves (25.0) and IAA, GA treated plant the numbers were 14.8 and 14.5 respectively at the end of fifth week of treatment. The minimum number of leaves was recorded in control (13.3) plants (Table 4).

\section{Number of branches}

During the experimental period, the number of branches was increased in all the treated plants when compared to the control plants at the end of fifth week. The maximum number of branches was recorded in Vermicompost 50\% (25.30), GA (18.8) and IAA (19.0). The number of branches was less significant in the control plants (Table 5).

NPK percentage in vermicompost-50\% treated soil was observed as $\mathrm{N}(1.95), \mathrm{P}(0.61)$ and $\mathrm{K}(0.08)$ which was higher than GA-treated soil $-\mathrm{N}(0.72), \mathrm{P}(0.22)$ and $\mathrm{K}(0.05)$ and IAA-treated soil - N (0.07), P (0.45) and K (0.04). The minimum NPK percentage was observed in the control soil samples, $\mathrm{N}(0.06), \mathrm{P}(0.002)$ and $\mathrm{K}(0.03)$.

Table 2 Effect of vermicompost and PGRs on the shoot length (cms) of C. annum

\begin{tabular}{|c|c|c|c|c|c|}
\hline Treatment & I week & II week & III week & IV week & V week \\
\hline Control & $8.09^{\mathrm{ab}} \pm 0.38(+80.9)$ & $8.85^{\mathrm{ab}} \pm 0.53(+88.5)$ & $9.13^{\mathrm{ab}} \pm 0.34(+91.3)$ & $10.32^{\mathrm{ab}} \pm 0.20(+103.2)$ & $\begin{array}{l}10.67^{\mathrm{ab}} \pm 0.24 \\
(+106.7)\end{array}$ \\
\hline Vermicompost-50\% & $10.45^{\mathrm{ab}} \pm 0.39(+104.5)$ & $13.82^{\mathrm{ab}} \pm 0.54(+138.2)$ & $15.87^{\mathrm{ab}} \pm 0.50(+158.7)$ & $17.14^{\mathrm{ab}} \pm 0.79(+171.4)$ & $\begin{array}{l}22.14^{\mathrm{ab}} \pm 0.79 \\
(+221.4)\end{array}$ \\
\hline GA & $10.05^{\mathrm{ab}} \pm 0.29(+100.5)$ & $12.32^{\mathrm{ab}} \pm 0.34(+123.2)$ & $15.27^{\mathrm{ab}} \pm 0.50(+152.7)$ & $16.74^{\mathrm{ab}} \pm 0.79(+167.4)$ & $\begin{array}{l}20.14^{\mathrm{ab}} \pm 0.56 \\
(+191.4)\end{array}$ \\
\hline IAA & $10.00^{\mathrm{ab}} \pm 0.36(+100.0)$ & $12.02^{\mathrm{ab}} \pm 0.44(+120.2)$ & $14.67^{\mathrm{ab}} \pm 0.50(+146.7)$ & $16.14^{\mathrm{ab}} \pm 0.79(+161.4)$ & $\begin{array}{l}18.14^{\mathrm{ab}} \pm 0.63 \\
(+181.4)\end{array}$ \\
\hline
\end{tabular}

Values are mean \pm S.E of 10 individual observations. Values in parentheses are percent change over control. Degrees of freedom $F \leq 0.05$

${ }^{a}$ Represents significance of variance between periods

${ }^{b}$ Represents significance of variance between treatments

Table 3 Effect of vermicompost and PGRs on internodal length (cms) of C. annum

\begin{tabular}{llllll}
\hline Treatment & I Week & II week & III week & IV week & V week \\
\hline Control & $1.30^{\mathrm{ab}} \pm 0.13(+13.0)$ & $1.37^{\mathrm{ab}} \pm 0.1(+13.7)$ & $1.49^{\mathrm{ab}} \pm 0.19(+14.9)$ & $1.55^{\mathrm{ab}} \pm 0.13(+15.5)$ & $1.66^{\mathrm{ab}} \pm 0.06(+16.6)$ \\
Vermicompost-50\% & $1.27^{\mathrm{ab}} \pm 0.13(+12.7)$ & $1.47^{\mathrm{ab}} \pm 0.09(+14.7)$ & $1.6^{\mathrm{ab}} \pm 0.06(+16.0)$ & $1.85^{\mathrm{ab}} \pm 0.05(+18.5)$ & $2.97^{\mathrm{ab}} \pm 0.15(+29.7)$ \\
GA & $1.30^{\mathrm{ab}} \pm 0.13(+13.0)$ & $1.39^{\mathrm{ab}} \pm 0.1(+13.9)$ & $1.49^{\mathrm{ab}} \pm 0.19(+14.9)$ & $1.55^{\mathrm{ab}} \pm 0.13(+15.5)$ & $2.17^{\mathrm{ab}} \pm 0.05(+21.7)$ \\
IAA & $1.27^{\mathrm{ab}} \pm 0.13(+12.7)$ & $1.4^{\mathrm{ab}} \pm 0.07(+14.0)$ & $1.5^{\mathrm{ab}} \pm 0.06(+15.0)$ & $1.65^{\mathrm{ab}} \pm 0.05(+16.5)$ & $1.77^{\mathrm{ab}} \pm 0.11(+17.7)$ \\
\hline
\end{tabular}

Values are mean \pm S.E of 10 individual observations. Values in parentheses are percent change over control. Degrees of freedom $F \leq 0.05$

${ }^{a}$ Represents significance of variance between periods

${ }^{\mathrm{b}}$ Represents significance of variance between treatments

Table 4 Effect of vermicompost and PGRs on the number of leaves ( $n$ ) of $C$. annum

\begin{tabular}{llllll}
\hline Treatment & I week & II week & III week & IV week & V week \\
\hline Control & $7.9^{\mathrm{ab}} \pm 0.7(+79.0)$ & $10.0^{\mathrm{ab}} \pm 0.71(+100.0)$ & $10.7^{\mathrm{ab}} \pm 0.61(+107.0)$ & $12.1^{\mathrm{ab}} \pm 0.78(+121.0)$ & $13.3^{\mathrm{ab}} \pm 0.59(+133.0)$ \\
Vermicompost-50\% & $8.3^{\mathrm{ab}} \pm 0.6(+83.0)$ & $13.0^{\mathrm{ab}} \pm 0.89(+130.0)$ & $16.7^{\mathrm{ab}} \pm 0.96(+167.0)$ & $17.9^{\mathrm{ab}} \pm 0.97(+179.0)$ & $25.0^{\mathrm{ab}} \pm 0.98(+250.0)$ \\
GA & $6.8^{\mathrm{ab}} \pm 0.0(+68.0)$ & $7.3^{\mathrm{ab}} \pm 0.39(+73.0)$ & $9.4^{\mathrm{ab}} \pm 0.42(+94.0)$ & $12.8^{\mathrm{ab}} \pm 0.44(+128.0)$ & $14.8^{\mathrm{ab}} \pm 0.34(+148.0)$ \\
IAA & $7.2^{\mathrm{ab}} \pm 0.71(+72.0)$ & $11.1^{\mathrm{ab}} \pm 0.47(+111.0)$ & $12.2^{\mathrm{ab}} \pm 0.41(+122.0)$ & $13.6^{\mathrm{ab}} \pm 0.76(+136.0)$ & $14.5^{\mathrm{ab}} \pm 0.80(+145.0)$ \\
\hline
\end{tabular}

Values are mean \pm S.E of 10 individual observations. Values in parentheses are percent change over control. Degrees of freedom $F \leq 0.05$

${ }^{a}$ Represents significance of variance between periods

${ }^{\mathrm{b}}$ Represents significance of variance between treatments 
Table 5 Effect of vermicompost and PGRs on the number of branches $(n)$ of $C$. annum

\begin{tabular}{|c|c|c|c|c|c|}
\hline Treatment & I week & II week & III week & IV week & V week \\
\hline 'ontrol & $6.9^{\mathrm{ab}} \pm 0.27(+69.0)$ & $7.7^{\mathrm{ab}} \pm 0.35(+77.0)$ & $9.6^{\mathrm{ab}} \pm 0.30(+96.0)$ & $11.3^{\mathrm{ab}} \pm 0.63(+113.0)$ & $5 \pm 0.53(+125.0)$ \\
\hline Verm & $8.2^{\mathrm{ab}} \pm 0.61(+82.0)$ & $12.8^{\mathrm{ab}} \pm 0.99(+128.0)$ & $15.8^{\mathrm{ab}} \pm 0.99(+158.0)$ & $18.5^{\mathrm{ab}} \pm 0.46(+185.0)$ & $25.0^{\mathrm{ab}} \pm 0.81(+250.0)$ \\
\hline GA & $6.8^{\mathrm{ab}} \pm 0.24(+68.0)$ & $11.2^{\mathrm{ab}} \pm 0.35(+112.0)$ & $14.5^{\mathrm{ab}} \pm 0.52(+145.0)$ & $16.5^{\mathrm{ab}} \pm 0.54(+165.0)$ & $18.8^{\mathrm{ab}} \pm 0.46(+188.0)$ \\
\hline IAA & $8.0^{\mathrm{ab}} \pm 0.51(+80.0)$ & $11.4^{\mathrm{ab}} \pm 0.67(+114.0)$ & $15.7^{\mathrm{ab}} \pm 0.73(+157.0)$ & $17.6^{\mathrm{ab}} \pm 0.90(+176.0)$ & $19.2^{\mathrm{ab}} \pm 0.61(+192.0)$ \\
\hline
\end{tabular}

Values are mean \pm S.E of 10 individual observations

Values in parentheses are percent change over control

${ }^{a}$ Represents significance of variance between periods

${ }^{\mathrm{b}}$ Represents significance of variance between treatments

Degrees of freedom $F \leq 0.05$

\section{Discussion}

In this study, the growth of plants was found to be significantly increased in plants treated with vermicompost. Plants treated with $50 \%$ vermicompost showed increased shoot length than GA- and IAA-treated plants. Studies by Atiyeh et al. (2002) reported the benefits of vermicompost as bedding media to promote seed germination, seedling growth and productivity of plants.

Organic amended in the form of vermicompost and vermiwash, when added to soil increase the yield and growth of plants. Length of the internode and diameter were increased significantly and maximum in vermicompost-treated plants than in GA- and IAA-treated plants. The increase in the diameter of internode can be related to increased girth of the plants. The observations in present study are in accordance with previous reports (Agarwal et al. (2003). An increase in the yield of certain vegetable crops such as brinjal, okra and tomato have been reported by Guerrero (2010), Gupta (2003), Sinha et al. (2009), Elumalai et al. (2013), respectively.

In plants treated with earthworm cast, the growth parameters of Triticum aesticum such as plant height, number of leaves and tillers, early ear heading, ear head length and dry matter per plant was found to be enhanced than the control plants (Nijhawan and Kanwar (1951). Emergence of tomato, cabbage and radish seedling was significant in vermicomposted soil than in thermophilically composted animal waste (Edward and Burrows 1988).

Biofertilizers contain a consortium of nutrients which are needed for plant growth. The NPK content of vermicompostamended soil was found to be enhanced when compared to the other amended soil. The soil amended with vermicompost provides the required nutrients, which are not available in chemically treated soil (Ansari and Ismail 2008). This increased nutrient uptake by plants may have contributed to maximum growth in vermicompost treated when compared to other treatments.
Vermicompost and vermiwash treatments improve the micronutrient levels in the soil (Jaikishaun et al. 2014). The carbon content in vermicomposted soil is found to release the nutrients slowly into the soil and thereby aiding the plants to absorb the available nutrients (Ansari and Sukhraj 2010).

Remarkable growth obtained in vermicompost-treated plants may be due to favorable and optimum temperature; moisture and a balance between organic and inorganic nutrients in the vermicompost have significantly aided in increased growth of plants. The enhanced growth in these plants may be due to improved soil health and the physico-chemical properties of soil were enhanced leading to an increase in both microbial activity and macro and micro nutrients. Vermicompost treatment enhanced the availability of nutrients in the soil (Singh et al. 2011).

Studies by Chauhan and Joshi (2010) reported a considerable increase of nitrogen in vermicomposted soil. The improvement of $\mathrm{N}_{2}$ content in the soil may be due to the nitrogen in the vermicast, which results in nitrogen mineralization aided by microbes in the soil, through the degradation of the earthworm tissues (Ananthakrishnasamy et al. 2009). Elimination of pathogens as of wastes like cow manure and sludge of wastewater treatment plant may be applied for soil improvement which is very essential in preventing the spread and transmission of disease (Karimi et al. 2017). The luxuriant growth, flowering and yield of the vegetable crops were promoted by the worms and vermicompost. The incidence of 'yellow vein mosaic; 'color rot' and 'powdery mildew' diseases was less in worm and vermicompost-treated plants.

\section{Conclusions}

The results of this study showed that $50 \%$ vermicompost treatment showed great potential to increase the performance, growth of chilly plant and improvement of soil quality. Chilly plants grown in vermicompost-amended soil showed enhanced growth rate when compared to plants 
treated with plant growth regulators (PGR). The study positively highlights the importance of organic farming; therefore, vermicompost may be put to good use as a natural fertilizer for cereals and vegetable crops for increased production and for sustainable agricultural systems.

Acknowledgements Authors are highly thankful to The Principal, Head of the department, Presidency College, Chennai, Tamil Nadu, India, for providing the facilities to carry out the work.

Open Access This article is distributed under the terms of the Creative Commons Attribution 4.0 International License (http://creativeco mmons.org/licenses/by/4.0/), which permits unrestricted use, distribution, and reproduction in any medium, provided you give appropriate credit to the original author(s) and the source, provide a link to the Creative Commons license, and indicate if changes were made.

\section{References}

Agarwal SB, Singh A, Dwivedi G (2003) Effect of vermicompost, farm yard manure and chemical fertilizers on growth and yield of wheat (Triticum aestivum L. var HD 2643). Plan Arch 3:9-14

Ananthakrishnasamy S, Sarojini S, Gunasekaran G, Manimegala G (2009) Flyash-a lignite waste management through vermicomposting by indigenous earthworms Lampito maruitii. Am Eurasian J Agric Environ Sci 5(6):720-724. https://www.idosi.org/aejaes/ aejaes.htm

Ansari, AA, Sukhraj K (2010) Effect of vermiwash and vermicompost on soil parameters and productivity of okra (Abelomoschus esculentus) in Guyana. Afr J Agric Res 5:1794-1798. http://www. academicjournals.org/AJAR. https://doi.org/10.5897/ajar09.107

Ansari AA Hanief A (2013) Microbial succession during vermicomposting. In: Proceedings of 49th Annual Carribean Food Crops Society Meeting. July 1-5, Port of spain, Trinidad and Tobago, p 441-451

Ansari AA, Ismail SA (2008) Relamation of sodic soils through vermitechnology. Pakistan J Agric Res 21:92-97

Ansari AA, Ismail SA (2012) Role of Earthworms in vermitechnology. J Agric Technol 8(2):405-415. http://www.ijat-aatsea.com

Arora VK, Singh CB, Sidhu AS, Thind SS (2011) Irrigation, tillage and mulching effects on Soybean yield and water productivity in relation to soil texture. Agric Water Manag 98(4):563-568. https ://doi.org/10.1016/j.agwat.2010.10.004

Atiyeh RM, Arancon NQ, Edwards CA, Metzger JD (2002) The influence of humic acid derived from earthworms processed organic wastes on the plant growth. Bioresour Technol 84(1):7-14

Chanda GC, Bhunia G, Chakraborty SK (2011) The effect of vermicompost and other fertilizers on cultivation of Tomato plants. J Hortic For 3: 42-45. http://www.academicjournals.org/jhf

Chaoui HI, Zibilske LM, Ohnot (2003) Effects of earthworms cast and compost on soil microbial activity and plant nutrient availability. Soil Biol Biochem 35:295-302. www.elsevier.com/locate/soilbio

Chauhan A, Joshi PC (2010) Composting of some dangerous and toxic weeds using Eisenia foetida. J Am Sci 6 (3):1-6. http://www. americanscience.org

Edward CA, Burrows I (1988) The potential of earthworm compost and plant growth media. In: Edward CA, Neuhauser IP (eds) Earthworm in waste Environmental Management. SPB Academic, Hague, pp 211-217

Elumalai D, Kaleena PK, Fathima M, Hemavathi H (2013) Influence of vermiwash and Plant growth regulators on the exomorphological characters of Abelmoschus esculentus (Linn.) Moench. Afri
J Basic Appl Sci 5(2):82-90. https://doi.org/10.5829/idosi.ajbas .2013.5.2.2332

Fathima M, Balasubramanian A (2006) Effect of plant growth regulators on the yield and quality of best fibers in Hibiscus sabdariffa $L$. var. altissima Wester. Int J Bot 2:48-55

Gemici GA, Kamil Yurekli A (2000) Effect of some growth regulators and commercial preparation on the chlorophyll content and mineral nutrition of Lycopersicm esculent Mill. Turk J Bot $24: 215-219$

Guerrero RD, (2010) Vermicompost production and its use for crop production in the Philippines; Int J Environ Eng (Special Issue on 'Vermiculture technology'); (Eds.) Rajiv K. Sinha et al. (Accepted for publication)

Gupta PK (2003) Vermicomposting for sustainable agriculture. Agrobios, India, p 188

Ismail SA (2005) The earthworm book. Other India Press, Mapusa, p 101

Jaikishun S, Hunte N, Ansari AA, Gomathinayagam S (2014) Effect of vermiwash from different sources (Bagasse, Neem, Paddy Straw in different combinations) in controlling fungal diseases and growth of tomato (Lycopersicon esculentum) Fruits in Guyana. J Biol Sci 14(8):501-507. https://doi.org/10.3923/jbs.2014.501.507

Karimi H, Mokhtari M, Salehi F, Sojoudi S, Ebrahimi A (2017) Changes in microbial pathogen dynamics during vermicomposting mixture of cow manure-organic solid waste and cow manuresewage sludge. Int J Recycl Org Waste Agric 6:57-61. https://doi. org/10.1007/s40093-016-0152-4

Manjunath Prasad CT (2008) Influence of nutrition and growth regulators on fruit, seed Yield and quality of pumpkin CV. Arka Chandan. Karnataka J Agrc Sci 21:115-117

Naeem M, Bhatti I, Hafeez Ahmed R, Yasin Asraf M (2004) Effect of some growth hormone (GA, IAA and Kinetin) on the morphology and early or delayed initiation of bud of lentil (Lens culinaris Meedik.). Pakistan J Bot 36:801-809

Nijhawan SD, Kanwar JS (1951) Physio-chemical properties of earthworm casting and their effect on the productivity of soil. India J Agric Sci 22(4):357-373

Ouzounidou G, Papadopoulou P, Giannakoula A (2010) Comparative Study on the various plant growth regulators on growth, quality and physiology of Capsicum annum. Pakistan J Bot 42:805-814

Parthasarthi K, Ranganathan LS (2002) Supplementation of presumed vermicast with NPK enhances growth and yield in Leguminous crops (Vigna mungo and Arachis hypogaea). J Carr Sci 2:35-41

Singh BK, Pathak KA, Verma AK, Verma VK, Deka BC (2011) Effects of vermicompost, fertilizer and mulch plant growth, nodulation and pod yield of French bean (Phaseolus vulgaris). Veg Crop Bulletin 74:153-165. https://doi.org/10.2478/v10032-011-0013-7

Sinha RK, Herat S, Valani D, Chauhan K (2009) Vermiculture and sustainable agriculture. Am Eurasian J Agric Environ Sci 5:1-55

Tejada M, Gonzalez JL (2004) Effects of foliar application of a byproduct of the two step olive oil mill process on rice yield. Euro J Agron 21:31-40

Varghese SM, Prabha ML (2014) Biochemical characterization of vermiwash and its effect on growth of Capsicum frutescens. Malaya J Biosci 1(2):86-91

Publisher's Note Springer Nature remains neutral with regard to urisdictional claims in published maps and institutional affiliations. 